\title{
Analisis Kesesuaian Artikel yang Menggunakan Model Pembelajaran STAD Berdasarkan Teori pada Buku Cooperative Learning Karya Robert E. Slavin
}

\author{
Lilla Pranti Mulyani*, Nunung Nurjanah, Teti Setiawati \\ Universitas Negeri Malang, Jl. Semarang No. 5 Malang, Jawa Timur, Indonesia \\ *Penulis korespondensi, Surel: nunung.nurjanah.ft@um.ac.id
}

Paper received: 09-03-2021; revised: 14-03-2021; accepted: 23-03-2021

\begin{abstract}
This research aims to analyze the suitability of using the STAD Learning Model in articles based on the Cooperative Learning Book by Robert E Slavin. The research method used is content analysis with a qualitative approach. The technique of drawing articles as a sample uses purposive sampling technique with reference to the article search instrument that has been prepared. There are five articles analyzed with the criteria of research articles using the STAD Learning Model, original research, applied to the Catering Expertise Competency Vocational School, and have a good completeness of the article content. The results showed that there was no suitability for the overall research objectives in the article, but the overall objectives of the study were related to theory. The learning syntax in the article is not fully implemented. The suitability of the research results in the article is shown by the achievement of the overall research objectives made even though they are different from the STAD Model learning objectives.
\end{abstract}

Keywords: STAD Learning Model; content analysis; Cooperative Learning Book by Robert E Slavin

\begin{abstract}
Abstrak
Penelitian ini bertujuan menganalisis kesesuaian menggunakan Model Pembelajaran STAD pada artikel berdasarkan Buku Cooperative Learning Karya Robert E Slavin. Metode penelitian yang digunakan adalah analisis isi dengan pendekatan kualitatif. Teknik penarikan artikel sebagai sampel menggunakan teknik purposive sampling dengan mengacu pada instrumen pencarian artikel yang telah disusun. Terdapat lima artikel yang dianalisis dengan kriteria artikel penelitian menggunakan Model Pembelajaran STAD, original research, diterapkan pada SMK Kompetensi Keahlian Tata Boga, serta memiliki kelengkapan isi artikel yang baik. Hasil penelitian menunjukan tidak terdapat kesesuaian pada keseluruhan tujuan penelitian pada artikel, namun keseluurhan tujuan penelitian tersebut memiliki keterkaitan dengan teori. Sintak pembelajaran pada artikel yang terlaksana dengan sesauai belum sepenuhnya. Kesesuaian hasil penelitian pada artikel ditunjukan dengan ketercapaian keseluruhan tujuan penelitian yang dibuat meskipun berbeda dengan tujuan pembelajaran Model STAD.
\end{abstract}

Kata kunci: model Pembelajaran STAD; Analisis isi; buku Cooperative Learning Karya Robert E Slavin

\section{Pendahuluan}

Tuntutan pendidikan di abad 21 mendorong agar dapat mencetak lulusan yang berkompeten dan berdaya saing sesuai dengan kemajuan zaman. Lulusan diharapkan dapat memiliki bekal untuk bersaing di dunia kerja pada era revolusi industri 4.0. Pergeseran pekerjaan mengalami perubahan berbasis industri (industrial age) menjadi (knowladge age) menurut (Trilling \& Fadel, 2009). Keterampilan yang dibutuhkan pada abad 21 ada tiga kategori. Menurut keterampilan yang dibutuhkan di abad 21 yaitu keterampialan belajar dan berinovasi, 
literasi digital, dan keterampilan hidup dan berkarir menurut (Sendeka \& Pilco, 2013). Sekolah menjadi tempat yang dapat membekali siswa untuk mengasah keterampilan belajar dan berinovasi.

Salah satu keterampilan abad 21 yang dapat dibentuk di sekolah adalah kemampuan belajar dan berinovasi. Menurut (Kinjuva, 2015) kemampuan belajar dan berinovasi meliputi empat keterampilan yaitu keterampilan berpikir kritis dan pemecahan masalah, komunikasi, kolaborasi, kreatif dan berinovasi. Social skills diperlukan sebagai wujud integrasi keterampilan abad 21 menurut (Alismail \& McGuire, 2015). Social skills juga merupakan aspek yang dibutuhkan dalam salah satu dari empat domain yang diperlukan dalam kesiapan kerja pada abad 21. Social skills merupakan elemen pada keterampilan hidup dan berkarir. Keterampilan abad 21 diperlukan untuk bekerja secara efektif dalam tim dengan anggota yang beragam. Pernyataan tersebut selaras dengan pernyataan (Kinjuva, 2015) yag menyebutkan bahwa dalam bekerja harus mampu membangun hubungan secara solid dengan orang yang berbeda etnik, ras, sosial dan latar belakang budaya.

Pernyataan tersebut didukung oleh (Sihite, 2018) salah satu indikator keterampilan sosial adalah responsif dalam pengembangan serta mampu membangun kerjasama dengan rekan kerja. Kemampuan berkolaborasi atau bekerjasama merupakan kunci untuk mengaitkan dan memadukan setiap kemampuan seseorang agar mendapatkan hasil kerja yang maksimal. Fakta empiris ditemukan bahwa siswa belum bisa menerapkan bentuk dari sikap bekerjasama. Sikap tersebut terlihat siswa yang merasa kurang mampu saat tergabung pada kelompok yang heterogen. Siswa yang merasa kurang mampu dan kurang kepercayaan diri cenderung akan menggantungkan hasil kerja pada anggota lain pada kelompok. Fenomena tersebut dapat diperbaiki dengan menggunakan model pembelajaran yang sesuai untuk membentuk dan meningkatkan kemampuan bekerjasama siswa.

Model pembelajaran Student Teams Achievement Division (STAD) merupakan model pembelajaran dari pendekatan kooperatif yang dapat meningkatkan kerjasama siswa melalui tanggung jawab individu (Slavin, 2005). Disebutkan juga pada Buku Cooperative Learning Karya Robert E. Slavin bahwa Model Pembelajaran STAD merupakan model pembelajaran yang memberikan pembagian andil peran yang sama dalam pencapaian kelompok. Ciri khas dari Model Pembelajaran STAD yang membedakan dengan model pembelajaran pada pendekatan kooperatif lain yaitu penggunaan kuis-kuis individual pada setiap akhir pembelajaran. Model pembelajaran STAD merupakan jenis model pembelajaran yang sederhana dan tertua dibandingkan dengan model pembelajaran lain pada pendekatan kooperatif (Slavin, 2005).

Penelusuran pada artikel mengenai penelitian penggunaan Model Pembelajaran STAD pada siswa SMK Kompetensi Keahlian Tata Boga cukup banyak dilakukan pada seluruh jenis mata pelajaran yang mencakup mata pelajaran muatan nasional (A), muatan kewilayahan (B), dan peminatan (C). Penggunaan model pembelajaran berdasarkan landasan yang kuat secara ilmiah menjadi tolok ukur keabsahan ketercapaian tujuan pembelajaran. Landasan teori utama tentang Model Pembelajaran STAD terdapat pada Buku Cooperative Learning Karya Robert E. Slavin. Berdasarkan latar belakang ini maka diperlukan penelitian yang menelaah isi dari hasil penelitian penggunaan Model Pembelajaran STAD berdasarkan Buku Cooperative Learning Karya Robert E. Slavin. Penelitian ini perlu dilakukan untuk menganalisis kesesuaian; 1) tujuan penelitian, 2) sintak pembelajaran, serta 3) hasil penelitian. Analisis tersebut perlu dikaji karena untuk melihat kesesuaian penelitian penggunaan Model Pembelajaran STAD dengan teori. Sesuai atau tidaknya penggunaan Model Pembelajaran STAD pada penelitan juga tergantung penyusunan dan pelaksanaan penelitian oleh peneliti. Seiring berjalannya waktu, artikel yang diteliti juga memiliki peluang mengalami perubahan seiring perkembangan tuntutan pendidikan. 
Berdasarkan kajian pada latar belakang tersebut maka disusun sebuah penelitian Analisis Kesesuaian Pengunaan Model Pembelajaran STAD Berdasarkan Teori Pada Buku Cooperative Learning Karya Robert E. Slavin.

\section{Metode}

Metode penelitian yang digunakan adalah analisis isi dengan pendekatan kualitatif. Teknik penarikan artikel sebagai sampel menggunakan teknik purposive sampling dengan mengacu pada instrumen pencarian artikel yang telah disusun. Terdapat lima artikel yang dianalisis dengan kriteria artikel penelitian menggunakan Model Pembelajaran STAD, original research, diterapkan pada SMK Kompetensi Keahlian Tata Boga, serta memiliki kelengkapan isi artikel yang baik. Penelitian dilakukan dengan cara meng-coding isi artikel berdasarkan instrumen coding. Data coding yang telah terkumpul diberi interpretasi sesuai intrumen hasil coding yang telah disusun. Hasil penelitian disajikan dalam bentuk tabel, kemudian dianalisis secara deskriptif kesesuaiannya.

\section{Hasil dan Pembahasan}

Penelitian analisis kesesuaian Model Pembelajaran STAD memiliki satu variabel dengan tiga tujuan. Setiap tujuan memiliki beberapa indikator yang dianalisis. Berikut ini akan diuraiakan analisis pada setiap tujuan penelitia yang akan di jabarkan pada setiap inidikator.

\subsection{Kesesuaian Tujuan Penelitian pada Artikel yang Menggunakan Model Pembelajaran STAD Berdasarkan Buku Cooperative Learning Karya Robert E. Slavin}

Artikel yang meneliti tentang Model Pembelajaran STAD tentu memiliki teori yang melandasi penelitiannya. Teori pada Buku Cooperative Learning karya Robert E Slavin menyebutkan bahwa tujuan pembelajaran Model STAD yaitu untuk meningkatkan kemampuan kerjasama siswa dan tanggung jawab individu. Hasil analisis kesesuaian tujuan penelitian dapat dilihat pada Tabel 1, Tabel 2, Dan Tabel 3.

Tabel 1. Hasil Analisis pada Indikator Kesesuaian Tujuan Penelitian dengan Tujuan Pembelajaran Model STAD

\begin{tabular}{|c|c|c|}
\hline $\begin{array}{l}\text { Kode } \\
\text { Artikel }\end{array}$ & $\begin{array}{l}\text { Hasil } \\
\text { Interpretasi }\end{array}$ & Keterangan Hasil Interpretasi \\
\hline $\begin{array}{l}\text { Artikel } 1 \\
\text { Artikel } 2 \\
\text { Artikel } 3 \\
\text { Artikel } 4 \\
\text { Artikel } 5\end{array}$ & Tidak sesuai & $\begin{array}{l}\text { Keseluruhan artikel mendapatkan hasil interpretasi "tidak } \\
\text { sesuai" karena tujuan penelitian pada artikel berbeda dengan } \\
\text { tujuan pembelajaran pada teori di Buku Cooperative Learning } \\
\text { karya Robert E Slavin. Tujuan pembelajaran Model STAD pada } \\
\text { teori yaitu untuk membentuk kemampuan kerjasama siswa dan } \\
\text { tanggung jawab individu. Sedangkan, tujuan pada artikel yang } \\
\text { berbeda-beda seperti meningkatkan hasil belajar, } \\
\text { meningkatkan motivasi belajar, meningkatkan prestasi belajar, } \\
\text { meningkatkan aktivitas belajar, meningkatkan kemampuan } \\
\text { belajar, dan meningkatkan pemahaman materi. }\end{array}$ \\
\hline
\end{tabular}

Tujuan pembelajaran Model STAD yaitu meningkatkan kerjasama siswa dan tangggung jawab inidividu, sedangkan pada artikel tujuan penlitian yang dibuat berbeda-beda. Ketidaksesuaian tujuan penelitian pada sampel penelitian yang menggunakan model pembelajaran STAD diduga dapat dipengaruhi oleh beberapa faktor. Pertama, keberhasilan penggunaan Model Pembelajaran STAD pada penelitian sebelumnya yang dapat memberikan 
manfaat selain membentuk kemampuan kerjasama seperti pada pernyataan (Marten, 2017). Kedua, ketertarikan peneliti untuk bereksperimen menggunakan Model Pembelajaran STAD dengan tujuan mencari solusi masalah pembelajaran. Ketiga, ketertarikan peneliti untuk mencari manfaat yang belum ditemukan oleh peneliti sebelumnya dalam menggunakan Model Pembelajaran STAD seperti pada penelitian (Siswanto, 2014). Berdasarkan uraian faktor penyebab tujuan penelitian artikel berbeda dengan teori, maka dapat disimpulkan bahwa perbedaan tujuan penelitian bukan kesalahan atau kekeliruan dari memahami konsep Model Pembelajaran STAD.

Tabel 2. Hasil Analisis pada Indikator Keterkaitan Tujuan Penelitian pada Artikel dengan Tujuan Pembelajaran Model Pembelajaran STAD

\begin{tabular}{lll}
\hline $\begin{array}{l}\text { Kode } \\
\text { Artikel }\end{array}$ & $\begin{array}{l}\text { Hasil } \\
\text { Interpretasi }\end{array}$ & Keterangan Hasil Interpretasi \\
\hline Artikel 1 & Terkait & Keseluruhan artikel mendapatkan hasil interpretasi terkait \\
Artikel 2 & & meskipun tujuan penelitian berbeda dengan teori. Interpretasi \\
Artikel 3 & & tersebut diberikan karena antara tujuan penelitian pada artikel \\
Artikel 4 & dengan alasan yang mendasari penggunaan Model \\
Artikel 5 & Pembelajaran STAD terdapat keterkaitan. Alasan yang \\
& mendasari pada keselurhan artikel yaitu mengarah pada \\
& keunggulan dari Model Pembelajaran STAD berupa kondisi \\
& positif yang terbentuk melalui berkelompok. Kondisi positif \\
& tersebut seperti adanya kegiatan diskusi, belajar bersama, \\
& memacu semangat antar anggota, bertanggung jawab, dan \\
& adanya keterlibatan anggota secara kolaboratif. \\
\hline
\end{tabular}

Indikator keterkaitan tujuan penelitian dengan teori digunakan untuk memberikan peluang ketercakupan alasan yang mendasari, jika tujuan penelitian berbeda dengan teori. Keterkaiatan tujuan penelitian didapat dari keselarasan antara tujuan penelitian (berbeda) dengan alasan yang mendasari keseluruhan peneliti memilih Model Pembelajaran STAD. Simpulan yang didapat dari telaah keseluruhan artikel keunggulan Model Pembelajaran STAD berupa kondisi positif dari kegiatan berkelompok secara heterogen. Kondisi positif tersebut berupa rasa saling dibutuhkan, saling memberi motivasi, membantu pemahaman materi,dan mendorong keaktifan antar siswa. Keterkaitan tujuan penelitian menunjukan bahwa ketidaksesuaian tujuan penelitian dengan tujuan pembelajaran Model Pembelajaran STAD tidak menjadi masalah yang menyalahi teori. Berdasarkan peningkatan kemampuan kerjasama siswa dan tanggung jawab individual ternyata menjadi alasan yang mendasari pada beberapa artikel untuk mencapai berbagai tujuan penelitian yang berbeda. Penelitian (Sudana \& Wesnawa, 2017) membuktikan dengan adanya pemberian kesadaran tentang tanggung jawab individu pada setiap kelompok, dapat meningkatkan hasil belajar. Kebermanfaatan model pembelajaran dengan tercapainya tujuan penelitian yang berbeda-beda akan semakin menambah kebermanfaatan dalam kemajuan pendidikan.

Tabel 3. Hasil Interpretasi pada Indikator Inovasi Model Pembelajaran STAD dengan Berbantuan Media/Model Pembelajaran

\begin{tabular}{lll}
\hline $\begin{array}{l}\text { Kode } \\
\text { Artikel }\end{array}$ & $\begin{array}{l}\text { Hasil } \\
\text { Interpretas } \\
\text { i }\end{array}$ & Keterangan Hasil Interpretasi \\
\hline Artikel 1 & Sesuai & $\begin{array}{l}\text { Berdasarkan telaah artikel 1 dan 3 didapatkan interpretasi } \\
\text { Artikel 3 }\end{array}$ \\
\hline
\end{tabular}




\begin{tabular}{|c|c|c|}
\hline $\begin{array}{l}\text { Kode } \\
\text { Artikel }\end{array}$ & $\begin{array}{l}\text { Hasil } \\
\text { Interpretas } \\
\text { i }\end{array}$ & Keterangan Hasil Interpretasi \\
\hline & & $\begin{array}{l}\text { media/model pembelajaran untuk mencapai tujuan } \\
\text { pembelajaran yang dirancang. Artikel } 1 \text { mengintegrasikan } \\
\text { bantuan LKS agar dapat memberi efesiensi waktu dalam } \\
\text { penyampaian materi dan pengerjaan kuis. Artikel } 3 \text { memilih } \\
\text { Model Pembelajaran Time Token untuk diintegrasikan pada } \\
\text { Model Pembelajaran STAD agar memberi kesempatan yang } \\
\text { sama pada semua anggota dalam kelompok untuk berbicara }\end{array}$ \\
\hline $\begin{array}{l}\text { Artikel } 2 \\
\text { Artikel } 4 \\
\text { Artikel } 5\end{array}$ & $\begin{array}{l}\text { Tidak } \\
\text { sesuai }\end{array}$ & $\begin{array}{l}\text { Berdasarkan telaah artikel yang dilakukan pada artikel 2,3, dan } \\
4 \text { mendapatkan interpretasi "tidak sesuai". Sebab pada ketiga } \\
\text { artikel tersebut tidak mengintegrasikan media/model } \\
\text { pembelajaran pada penggunaan Model Pembelajaran STAD. }\end{array}$ \\
\hline
\end{tabular}

Tujuan telaah pada intikator ini yaitu untuk mengetahui ada tidaknya inovasi yang diintegrasikan pada Model Pembelajaran STAD. Setelah itu, fokus analisis dilihat bagaimana kesesuaian bantuan pada Model Pembelajaran STAD yang dipilih. Sebab adanya bantuan meida/model pembelajaran sebagai bentuk pengembangan atau penyempurnaan. Jika pada artikel tidak diberikan inovasi, hal tersebut juga tidak menyalahi teori selama semua tahapan sintak pembelajaran diterapkan dengan benar. Jenis bantuan media/metode pembelajaran yang diintegrasikan dengan Model Pembelajaran STAD yaitu penggunaan lembar kerja siswa (LKS) dan integrasi Model Pembelajaran time token.

\subsection{Kesesuaian Sintak Pembelajaran pada Artikel yang Menggunakan Model Pembelajaran STAD Berdasarkan Buku Cooperative Learning Karya Robert E. Slavin}

Sintak pembelajaran merupakan kerangka utama yang membentuk setiap jenis model pembelajaran. Sintak pada model pembelajaran menjadi sarana untuk mencapai tujuan pembelajaran. Menurut (Slavin, 2005) sintak pembelajaran Model STAD meliputi presentasi pembelajaran, pembentukan kelompok, kuis individual, perhitungan skor kemajuan individu, dan penghargaan kelompok. Hasil analisis keseusaian sintak pembelajaran terdapat pada tabel 4 s.d tabel 8. dan Berikut ini penyajian hasil analisis dan pembahasan dari setiap indikator kesesuaian sintak pembelajaran.

Tabel 4. Hasil Analisis pada Indikator Kesesuaian Tahap Presentasi Pembelajaran pada Artikel yang Menggunakan Model Pembelajaran STAD

\begin{tabular}{|c|c|c|}
\hline $\begin{array}{l}\text { Kode } \\
\text { Artikel }\end{array}$ & $\begin{array}{l}\text { Hasil } \\
\text { Interpretasi }\end{array}$ & Keterangan Hasil Interpretasi \\
\hline $\begin{array}{l}\text { Artikel } 1 \\
\text { Artikel } 2\end{array}$ & Sesuai & $\begin{array}{l}\text { Telaah artikel menunjukan bahwa artikel } 1 \text { dan } 2 \text { mendapatkan } \\
\text { interpretasi "sesuai". Temuan hasil coding artikel } 1 \text { menjelaskan } \\
\text { keterlaksanaan presentasi pembelajaran menggunakan bantuan } \\
\text { lembar kerja siswa (LKS). Pengunaan LKS diharapkan dapat } \\
\text { menghemat waktu dan mendorong siswa belajar bersama } \\
\text { teman dalam kelompoknya. Berdasarkan artikel } 2 \text { pelaksanaan } \\
\text { presentasi pembelajaran dilakukan oleh guru. Mengacu pada } \\
\text { informasi yang tertulis pada artikel penyampaian presentasi } \\
\text { pembelajaran dan penyampaian materi tanpa menggunakan } \\
\text { bantuan media }\end{array}$ \\
\hline Artikel 4 & Hanya & Artikel 4 dan 5 mendapat interpretasi "hanya disinggung". \\
\hline Artikel 5 & disinggung & Interpretasi tersebut diberikan karena tidak ada informasi \\
\hline
\end{tabular}




\begin{tabular}{lll}
\hline $\begin{array}{l}\text { Kode } \\
\text { Artikel }\end{array}$ & $\begin{array}{l}\text { Hasil } \\
\text { Interpretasi }\end{array}$ & Keterangan Hasil Interpretasi \\
\hline & & $\begin{array}{l}\text { mengenai pelaksanaan presentasi pembelajaran pada } \\
\text { penelitian, namun dijelaskan secara teori pada latar belakang } \\
\text { dan kajian pustaka. }\end{array}$ \\
\hline Artikel 3 & Tidak sesuai & $\begin{array}{l}\text { Artikel 3 mendapat interpretasi "tidak sesuai" karena tidak ada } \\
\text { penjelasan baik secara teori dan secara pelaksanaan mengenai } \\
\text { presentasi pembelajaran. }\end{array}$ \\
\hline
\end{tabular}

Presentasi pembelajaran yang terlaksana dengan sesuai dari keseluruhan artikel hanya ada 2 artikel. Adanya presentasi pembelajaran dapat memberi pemahaman tentang gambaran pembelajaran serta tujuan akhir dari pembelajaran. Menurut (Slavin, 2005) presentasi pembelajaran mencakup pembukaan, pengembangan, dan penjelasan singkat dari materi pelajaran. Pelaksanaan presentasi pembelajaran yang tersampaikan dengan baik akan mendorong siswa untuk menjalankan semua tahap pembelajaran dengan baik. Sebab kesadaran siswa sebelum belajar sebagai bentuk kesiapan belajar. Siswa yang telah siap dalam belajar akan dapat menerima materi yang diberikan dengan baik. Kelompok yang telah berhasil kompak dan siap belajar sejak awal pembelajaran akan dapat memudahkan ketercapaian tujuan akhir kelompok. Selaras dengan pernyataan (Jayadiningrat, Tika, \& Yuliani, 2017) semakin baik kesiapan belajar siswa maka semakin baik hasil belajar yang diperoleh.

Tabel 5. Hasil Analisis pada Indikator Kesesuaian Tahap Pembentukan Kelompok pada Artikel

\begin{tabular}{|c|c|c|}
\hline $\begin{array}{l}\text { Kode } \\
\text { Artikel }\end{array}$ & $\begin{array}{l}\text { Hasil } \\
\text { Interpretasi }\end{array}$ & Keterangan Hasil Interpretasi \\
\hline Artikel 2 & Sesuai & $\begin{array}{l}\text { Mengacu pada instrumen penarikan interpretasi, artikel } 2 \\
\text { mendapatkan interpretasi "sesuai” karena baik secara teori dan } \\
\text { pelaksanaan dijelaskan. Namun, berdasarkan penelusuran } \\
\text { informasi tentang teknik pembentukan kelompok pada artikel } \\
\text { tidak dijelaskan. Sehingga, tidak diketahui apakah } \\
\text { pembentukan kelompok telah mengacu cara pembentukan } \\
\text { kelompok Model Pembelajaran STAD atau belum }\end{array}$ \\
\hline Artikel 1 & Hanya & Artikel 1, 3, 4, dan 5 mendapat interpretasi "hanya disinggung". \\
\hline Artikel 3 & disinggung & Interpretasi tersebut diberikan karena tidak ada informasi \\
\hline Artikel 4 & & mengenai pelaksanaan pembentukan kelompok pada \\
\hline Artikel 5 & & $\begin{array}{l}\text { penelitian, namun dijelaskan secara teori pada latar belakang } \\
\text { dan kajian pustaka. }\end{array}$ \\
\hline
\end{tabular}

Pembentukan kelompok belajar yang terlaksana dengan sesuai hanya ada pada 1 artikel. Tujuan pembentukan kelompok pada Model Pembelajaran STAD adalah memberikan kesempatan setiap siswa untuk diskusi memahami materi agar dapat mengerjakan kuis individual dengan baik dan dapat mencapai tujuan kelompok. Tujuan akhir kelompok adalah mendapat total tertinggi dari setiap skor kemajuan anggota kelompok. Tercapainya skor tertinggi pada, mencerminkan pemahaman yang meningkat pada setiap anggota. Belajar berkelompok menggunakan prinsip ketergantungan positif, sehingga tidak diharapkan adanya siswa yang pasif dan menggantungkan ketercapaian hasil kelompok pada teman yang dianggap mampu. Pembentukan kelompok secara heterogen, memberikan kesempatan bagi siswa yang berprestasi rendah untuk belajar bersama siswa yang memiliki kemampuan berprestasi tinggi. 
Tabel 6. Hasil Analisis pada Indikator Kesesuaian Tahap Kuis Individual pada Artikel yang Menggunakan Model Pembelajaran STAD

\begin{tabular}{|c|c|c|}
\hline $\begin{array}{l}\text { Kode } \\
\text { Artikel }\end{array}$ & $\begin{array}{l}\text { Hasil } \\
\text { Interpretasi }\end{array}$ & Keterangan Hasil Interpretasi \\
\hline $\begin{array}{l}\text { Artikel } 1 \\
\text { Artikel } 2 \\
\text { Artikel } 4 \\
\text { Artikel } 5\end{array}$ & Sesuai & $\begin{array}{l}\text { Artikel 1, 2, 4, dan } 5 \text { mendapatkan interpretasi "sesuai" karena } \\
\text { ada penjelasan mengenai kuis individual baik secara teori dan } \\
\text { pelaksanaannya. Keempat artikel tersebut menggunakan } \\
\text { lembar kertas sebagai alat bantu pengerjaan kuis, sehingga } \\
\text { belum ada media pendukung yang membantu efektifitas dan } \\
\text { efisiensi perjaan kuis individu, }\end{array}$ \\
\hline
\end{tabular}

Kuis individual yang terlaksana dengan sesuai terlaksana ada 4 artikel. Kuis individual adalah tahapan pembelajaran pada sintak Model Pembelajaran STAD yang melatih siswa untuk bertanggung jawab secara individu.

Beberapa permasalahan siswa dalam berkelompok seperti menggantungkan hasil pada siswa yang berprestasi tinggi dapat dicegah dengan pemberian tanggung jawab individu setiap anggota untuk mencapai tujuan kelompok. Setiap siswa memiliki keharusan untuk mengerjakan kuis individu meskipun tergabung dalam kelompok belajar. Kuis tidak dikerjakan atas nama kelompok, namun tetap atas nama individu. Temuan hasil penelitian menunjukan keseluruhan kuis dilakukan dengan menggunakan kertas dalam bentuk pilihan ganda maupun tugas terstruktur. Temuan yang didapatkan pada artikel 1 yaitu adanya bantuan LKS yang dimaksudkan untuk memberi kepraktisan guru dalam memberikan materi, instruksi berdiskusi, dan kuis.

Tabel 7 Hasil Analisis pada Indikator Kesesuaian Tahap Perhitungan Skor Kemajuan Individual Model Pembelajaran STAD pada Artikel

\begin{tabular}{lll}
\hline $\begin{array}{l}\text { Kode } \\
\text { Artikel }\end{array}$ & $\begin{array}{l}\text { Hasil } \\
\text { Interpretasi }\end{array}$ & Keterangan Hasil Interpretasi \\
\hline Artikel 1 & Tidak sesuai & Keseluruhan artikel mendapatkan interpretasi “tidak \\
Artikel 2 & & sesuai" karena tidak ada artikel yang menjelaskan baik \\
Artikel 3 & & secara teori dan pelaksanaan penelitian terkait \\
Artikel 4 & perhitungan skor kemajuan individual. Perhitungan skor \\
Artikel 5 & terbatas sampai perolehan nilai setiap siswa. Artikel 1 \\
& melakukan perhitungan rata-rata skor setiap siswa hingga \\
& post test. Artikel 2 melakukan pembahasan untuk soal \\
& yang sulit. Artikel 3 memberi evaluasi soal di akhir \\
& pembelajaran. Artikel 3 dan 5 tidak diketahui tentang \\
& perhitungan skor. \\
\hline
\end{tabular}

Perhitungan skor kemajuan individu tidak ada yang terlaksana dengan sesuai. Ada beberapa yang menghitung rata-rata skor atau hanya menghitung skor hasil kuis setiap siswa. Ada juga penelitian yang hanya mengetahui hasil kuis biasanya sebagai data untuk mengetahui hasil belajar siswa. Padahal perhitungan skor kemajuan individu merupakan ciri khas dari sintak pembelajaran Model STAD menurut Buku Cooperative Learning karya Robert E Slavin. Skor kemajuan individu merupakan kegiatan menghitung selisih skor antara skor awal dan skor hasil kuis individu. Skor kemajuan setiap anggota akan mempengaruhi rata-rata skor kemajuan pada kelompok. Skenario pembelajaran pada tahap ini dapat memacu siswa untuk memberikan andil terbaik agar dapat memberikan pengaruh positif rata- rata skor kemajuan dalam kelompok. Konsep tentang tanggung jawab individu pada Model Pembelajaran STAD, 
juga akan membuat siswa merasa dirinya dibutuhkan dalam kelompok atau disebut bentuk aktualisasi diri. Rasa minder pada siswa yang kurang berprestasi dapat dikurangi dengan adanya kesempatan yang sama setiap siswa untuk meraih hasil skor kemajuan individu yang terbaik.

Tabel 8. Hasil Analisis pada Indikator Kesesuaian Tahap Penghargaan Kelompok Model Pembelajaran STAD pada Artikel

\begin{tabular}{|c|c|c|}
\hline $\begin{array}{l}\text { Kode } \\
\text { Artikel }\end{array}$ & $\begin{array}{l}\text { Hasil } \\
\text { Interpretasi }\end{array}$ & Keterangan Hasil Interpretasi \\
\hline $\begin{array}{l}\text { Artikel } 1 \\
\text { Artikel } 2 \\
\text { Artikel } 3 \\
\text { Artikel } 4\end{array}$ & $\begin{array}{l}\text { Hanya } \\
\text { disinggung }\end{array}$ & $\begin{array}{l}\text { Artikel 1, 2, 3, dan } 4 \text { mendapat interpretasi “hanya } \\
\text { disinggung" karena hanya membahas secara teori di latar } \\
\text { belakang dan tidak dijelaskan pada tahap pelaksanaan } \\
\text { penelitian. }\end{array}$ \\
\hline Artikel 5 & Tidak sesuai & $\begin{array}{l}\text { Artikel } 5 \text { mendapatkan interpretasi "tidak sesuai" karena } \\
\text { tidak ada penjelasan baik secara teori ataupun praktik } \\
\text { tentang penghargaan kelompok. }\end{array}$ \\
\hline
\end{tabular}

Penghargaan Kelompok tidak ada yang terlaksana dengan sesuai. Keseluruhan artikel yang diteliti hanya melakukan sampai tujuan penelitian tercapai. Pernghargaan atas proses belajar dan usaha siswa masih belum diberikan. Penghargaan kelompok adalah bentuk apresiasi atas usaha seluruh anggota kelompok. Bentuk penghargaan yang diberikan bervariasi mualai dari pernghargaan untuk kelompok yang meraih total skor tertinggi hingga kelompok yang mendapatkan totsl skor terendah. Semua kelompok mendapatkan penghargaan sebagai bentuk apresiasi. Apresiasi dalam pembelajaran dibutuhkan untuk memberi semangat dan pengakuan atas usaha yang telah dilakukan siswa saat belajar.

\subsection{Kesesuaian Hasil Penelitian pada Artikel yang Menggunakan Model Pembelajaran STAD Berdasarkan Tujuan Pembelajaran Menurut Teori pada Buku Cooperative Learning Karya Robert E. Slavin}

Hasil penelitian butuh dianalisis dan dibahas karena melalui hasil penelitian dapat memberikan gambaran ketercapaian tujuan penelitian pada artikel dalam menggunakan model Pembelajaran STAD. Hasil analisis keseusaian hasil pebelitian terdapat pada tabel 9 dan tabel 10. Berikut ini penyajian hasil analisis dan pembahasan dari setiap indikator kesesuaian hasil penelitian.

Tabel 9. Hasil Analisis pada Indikator Kesesuaian Hasil Penelitian dengan Tujuan Penelitian pada Artikel yang Menggunakan Model Pembelajaran STAD

\begin{tabular}{lll}
\hline Kode & Hasil & Keterangan Hasil Interpretasi \\
Artikel & Interpretasi & \\
\hline Artikel 1 & Sesuai & Keseluruhan artikel mendapatkan interpretasi "sesuai" \\
Artikel 2 & & karena keseluruhan hasil penelitian pada artikel dapat \\
Artikel 3 & & mencapai tujuan penelitian yang dibuat. \\
Artikel 4 & & \\
Artikel 5 & & \\
\hline
\end{tabular}

Hasil penelitian menunjukan bahwa keseluruhan artikel memiliki kesesuaian antara hasil penelitian dengan tujuan penelitiannya. Pemilihan Model Pembelajaran STAD untuk mencapai tujuan penelitian tentu harus berdasarkan landasan yang kuat secara ilmiah. Hal 
tersebut diperlukan untuk meminimalisir adanya kegagalan dalam mencapai tujuan penelitian dengan menggunakan Model Pembelajaran STAD. Kajian ilmiah juga dibutuhkan untuk memberikan inovasi pada sisi kekurangan yang ditemukan pada Model Pembelajaran STAD. Berdasarkan (Slavin, 2005) Model Pembelajaran STAD sesuai digunakan untuk mata pelajaran teori. Sehingga, jika ada mata pelajaran yang membutuhkan praktik, Model Pembelajaran STAD baik digunakan saat penyampaian materi dan latihan soalnya.

Tabel 10. Hasil Analisis Keterkaitan Hasil Penelitian dengan Tujuan Pembelajaran Model STAD

\begin{tabular}{lll}
\hline Kode & Hasil & Keterangan Hasil Interpretasi \\
Artikel & Interpretasi & Keseluruhan artikel mendapat interpretasi “terkait” karena \\
\hline Artikel 1 & Terkait & hasil penelitian dapat tercapai berlandaaskan latar \\
Artikel 2 & & belakang penelitian sebagai pijakan teori. \\
Artikel 3 & & \\
Artikel 4 & & \\
Artikel 5 & & \\
\hline
\end{tabular}

Hasil penelitian menunjukan keseluruhan dari artikel penelitian memiliki tujuan penelitian yang berbeda, namun memiliki keterkaitan dengan teori. Keterkaitan dengan teori ditunjukan berdasarkan alasan peneliti memilih Model Pembelajaran STAD untuk mencapai tujuan penelitian. Persamaan Keunggulan Model Pembelajaran STAD berdasarkan temuan hasil penelitian berupa terbentuknya kegiatan positif saat kerja kelompok dan hasil positif dari interaksi kerjasama antar anggota. Beberapa artikel juga menyoroti kekurangan dari model pembelajaran STAD sehingga menggunakan bantuan media untuk mencapai tujuan penelitian. Landasan teori yang mendasari peneliti dibuktikan dengan ketercapaian hasil penelitian pada artikel. Sehingga keterkaitan antara landasan teori dengan pemilihan Model Pembelajaran STAD, sebagai indikasi keberhasilan penelitian yang dilakukan.

\section{Simpulan}

Berdasarkan hasil penelitian dan pembahasan dapat ditarik kesimpulan sebagai berikut: 1) Kesesuaian tujuan penelitian pada keseluruhan artikel tidak ditemukan, karena semua tujuan penelitiannya berbeda. Perbedaan tujuan penelitian pada artikel dengan tujuan pembelajaran Model STAD bukan kekeliruan dari memahami konsep Model Pembelajaran STAD. Keterkaitan ditemukan antara alasan yang mendasari pemilihan Model Pembelajaran STAD dengan penentuan tujuan penelitian yang berbeda. Adanya inovasi Model Pembelajaran STAD juga menjadi salah satu sarana untuk mencapai tujuan penelitian yang berbeda. 2) Kesesuaian sintak Model Pembelajaran STAD sebagai berikut: a) Presentasi pembelajaran yang terlaksana dengan sesuai dari keseluruhan artikel hanya ada 2 artikel; b) Pembentukan kelompok belajar yang terlaksana dengan sesuai hanya ada pada 1 artikel; c) Kuis individual yang terlaksana dengan sesuai terlaksana ada 4 artikel; d) Perhitungan skor kemajuan individu tidak ada yang terlaksana dengan sesuai; e) Penghargaan kelompok tidak ada yang terlaksana dengan sesuai. 3) Kesesuaian hasil penelitian pada artikel ditunjukan dengan ketercapaian keseluruhan tujuan penelitian yang dibuat meskipun berbeda dengan tujuan pembelajaran Model STAD. Keabsahan keberhasilan tersebut diperkuat dengan bukti adanya keterkaitan yang mendasari pemilihan Model Pembelajaran STAD untuk mencapai tujuan penelitian yang berbeda. 


\section{Daftar Rujukan}

Alismail, H. A., \& McGuire, P. (2015). 21st Century Standards and Curriculum: Current Research and Practice. Journal of Education and Practice , 6 (6), 150-155.

Jayadiningrat, M., Tika, I., \& Yuliani, N. (2017). Meningkatkan Kesiapan dan Hasil Belajar Siswa pada Pembelajaran Kimia dengan Pemberian Kuis di Awal Pembelajaran. Jurnal Pendidikan Kimia Indonesia ,1(1), 7-12.

Kinjuva, C. (2015). Teaching Students to Learn and Work Well with 21st Century Skills: Unpacking the career anf lifre Skills Domain of the New LEarning paradigm. International Journal of Higher Education , 4(1), $1-11$.

Marten. (2017). Peningkatan Kerjasama dan Prestasi Belajar Matematika Siswa Kelas V SD Karitas Tahun Pelajaran 2016/2017 Melalui Penerapan Model Pembelajaran Kooperatif Tipe Student Team Achievement Division (STAD). Skripsi tidak diterbitkan.Yogyakarta: FKIP Universitas Sanata Dharma.

Sendeka, S. \& Pilco, S. (2013). Evolution of the Framework for 21st Century Competencies. Knowladge Management \& E-Learning , 5(1), 10-24.

Sihite, M. (2018). Peran Kompetensi dalam Mewujudkan Sumber Daya Manusia yang Berdaya Saing Tinggi di Era Revolusi Industri 4.0: Suatu Tinjauan konseptual. Jurnal Ilmiah Methonomi , 4(2), 145-159.

Siswanto, R. (2014). Peningkatan Kemampuan Penalaran Dan Koneksi Matematis Melalui Penerapan Model Pembelajaran Kooperatif Tipe Stad Berbantuan Software Geogebra (Studi Eksperimen Di SMAN 1 Cikulur Kabupaten Lebak Propinsi Banten). Jurnal Pendidikan dan keguruan , 1(1), 1-11.

Slavin, R. E. (2005). Cooperative Learning: Teori, Riset dan Praktik. (T. N. Yusron, Ed.) Bandung: Nusa Media.

Sudana, I., \& Wesnawa, I. (2017). Penerapan Model Pembelajaran Kooperatif Tipe STAD untuk Meningkatkan Hasil Belajar IPA. Jurnal Ilmiah Skolah Dasar , 1 (1), 1-8.

Trilling, B., \& Fadel, C. (2009). 21st century Skill: Learning for Life in Our Times. San Francisco: Jossey-Bass/Willy \& Son, Inc. 